\title{
Effect of Reinforcement on Deflection and Cracks in Baked Clay Beams Subjected to Impact Loading
}

\author{
Nawab Ali Lakho, Muhammad Auchar Zardari* \\ Department of Civil Engineering, Quaid-e-Awam University of Engineering, Science and Technology, Nawabshah, Pakistan \\ Email: *muhammad.auchar@quest.edu.pk
}

How to cite this paper: Lakho, N.A. and Zardari, M.A. (2016) Effect of Reinforcement on Deflection and Cracks in Baked Clay Beams Subjected to Impact Loading. Engineering, 8, 691-696. http://dx.doi.org/10.4236/eng.2016.810063

Received: September 3, 2016

Accepted: October 9, 2016

Published: October 12, 2016

Copyright $\odot 2016$ by authors and Scientific Research Publishing Inc. This work is licensed under the Creative Commons Attribution International License (CC BY 4.0).

http://creativecommons.org/licenses/by/4.0/

\begin{abstract}
Attempts are being made to utilize Reinforced Baked Clay (RBC) as a substitute of Reinforced Cement Concrete (RCC) for construction of low cost houses in plains of Pakistan. Since baked clay is considered to be more brittle as compared to concrete. Therefore, it is necessary to investigate how deflection and crack width of RBC beams subjected to impact loading are governed by amount of reinforcement. This paper presents the behaviour of RBC beams under drop weight impact loading. The beams were reinforced with two steel bars, one in compression zone and the other in tension zone. In group A beams, the diameter of steel bars was $12.7 \mathrm{~mm}$, while the beams of group B were reinforced with steel bars of $15.8 \mathrm{~mm}$ diameter. The RBC beams were subjected to repeated impacts of a hammer of mass $21 \mathrm{~kg}$ falling from a height of $1000 \mathrm{~mm}$. The results show that 1) three times reduction in deflection, and 2) 2.5 times decrease in crack width, were achieved in RBC beams by increasing the area of steel to $50 \%$. In addition to this, all the RBC beams failed within nine blows of the hammer, irrespective of area of reinforcement.
\end{abstract}

\section{Keywords}

Reinforced Baked Clay, Impact Load, Deflection, Cracks, Compressive Strength

\section{Introduction}

Due to high cost of cement, and aggregates in plains of Pakistan, attempts are being made to search for other indigenous and low cost materials of building construction. In this regard, baked clay is considered to be a potential material for construction of low cost houses. Preliminary studies report that the compressive strength of baked clay is comparable to that of normal weight concrete [1]-[7]. Research has been carried out on flexural behaviour of laboratory size Reinforced Baked Clay (RBC) beams. The studies suggest that the load carrying capacity of RBC beams is also comparable to that of RCC 
beams [8].

If a structural member is subjected to an impact load, more stresses and deformations could be developed as compared to static loads. Impact loads include shock waves and vibrations from explosions, earthquakes, nearby rail roads, or movement of heavy machinery near a structure. A structure would normally resist a static load, but if the load of same magnitude is applied as an impact load, it could cause comparatively more damage to it.

At present, public and government buildings, all over the world, are being targeted with terrorist attacks. For public safety, structural engineers are paying more attention to design buildings which could sustain impact loads caused by explosions. For this purpose, it is important to investigate the effect of impact loading on materials of building construction. Like concrete, baked clay is a brittle material, it may exhibit complex cracking behaviour when subjected to impact loading [9]. The impact loading can cause the beam to crack in tension or the failure in compression zone or both [10]. The failure of baked clay due to crushing in compression zone at the point of impact can cause brittle mode of failure, which is considered to be undesired in structures. If the impact load causes the beams to crack in tension zone, water could get access to the reinforcement, which in turn may cause rusting of steel bars and failure with time [11]. If the material of the beams is impact resistant, increase in ratio of reinforcement can increase the strength of the beams against impact loading [12]. The authors are of the view that no study regarding the effect of reinforcement on deflection and cracking behaviour of baked clay beams subjected to impact loading is reported in the literature. In this regard, an experimental programme was performed to investigate the effect of reinforcement on deflection and cracking behaviour of baked clay beams subjected to impact loading.

\section{Materials and Methods}

\subsection{Casting of Clay Beams}

Indigenous clay was pulverized and was mixed with local pit-sand. The clay and pitsand mixture was prepared in a ratio of 70:30 by weight. The quantity of water added was $22 \%$ of the clay and pit sand. The mixing was performed in a pan mixer for fifteen minutes. This moist mixture was covered with plastic sheet and was placed for 24 hours. For convenience, from now on, the mixture is referred to as moist clay. Beams of dimensions $150 \mathrm{~mm} \times 300 \mathrm{~mm} \times 1980 \mathrm{~mm}$ were cast in Mechanized System (Figure 1) [13]. These moist clay beams were compacted at $3 \mathrm{MPa}$ in drained state condition [6] during the process of casting. After compaction, these clay beams were dried in shade. These dried clay beams were fired in a Potter's type kiln at $1000^{\circ} \mathrm{C}$ (Figure 2).

\subsection{Testing Programme}

Five cubes of $150 \mathrm{~mm}$ size were sawed from these baked clay beams and tested in Universal Testing Machine for compressive strength (Figure 3). The compressive strength test was performed in accordance with British Standard BS EN 12390-3 [14]. Six beam 


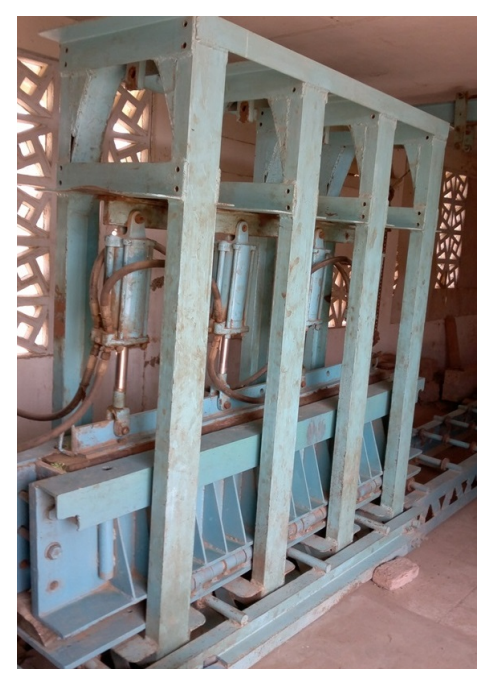

Figure 1. A clay beam is being cast and compacted in mechanized system.

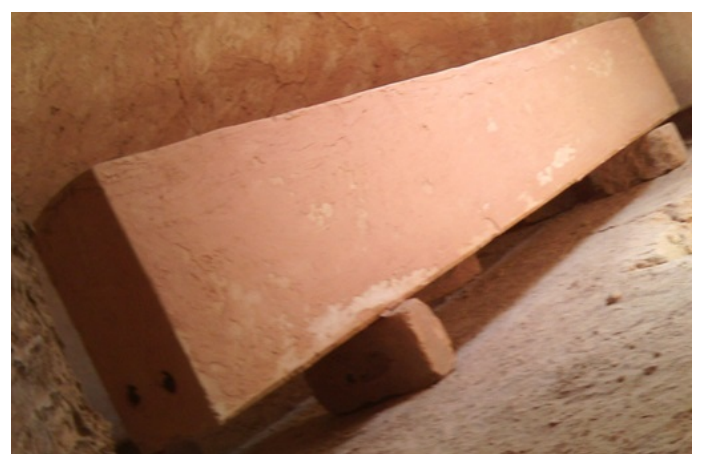

Figure 2. A view of a baked clay beam after firing in Potter's type kiln.

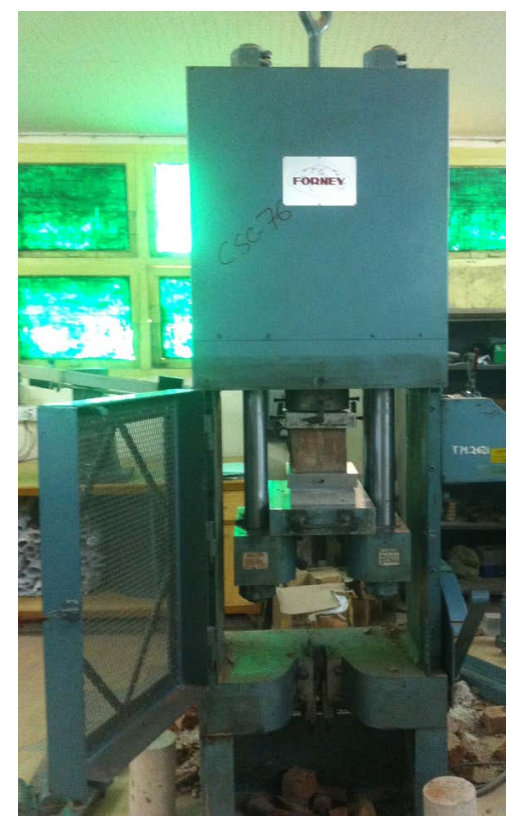

Figure 3. Determination of compressive strength of a baked clay cube in Universal Testing Machine. 
prisms of $150 \mathrm{~mm}$ square in cross section and $500 \mathrm{~mm}$ long were sawed from these baked clay beams. The baked clay beam prisms were reinforced using two steel bars, one in compression zone and other in tension zone. The baked clay beam prisms were divided into two groups based on diameter of steel reinforcement. Group A beams were reinforced with two steel bars each of diameter $12.7 \mathrm{~mm}$. The beams of group B were reinforced with two steel bars each of diameter $15.8 \mathrm{~mm}$. These beam prims were tested under drop weight impact loading. For this purpose, drop weight impact load testing machine, designed and fabricated by the authors, was utilized (Figure 4). In this test, a hammer of mass $21 \mathrm{~kg}$ was used. The hammer was dropped manually from a height of $1000 \mathrm{~mm}$.

\section{Results and Discussions}

Reinforced baked clay beam prisms belonging to group A (reinforced with two steel bars each of diameter $12.7 \mathrm{~mm}$ ) and group B (reinforced with two steel bars each of diameter $15.8 \mathrm{~mm}$ ) were tested under drop weight impact loading.

\subsection{Cube Crushing Strength of Baked Clay}

Five cubes of $150 \mathrm{~mm}$ size were cut from baked clay beams and tested in Universal Testing Machine. Average compressive strength of the cubes was found to be $20 \mathrm{MPa}$. It may be noted that compressive strength of normal weight concrete is generally considered as $20 \mathrm{MPa}$. This implies that the compressive strength of baked clay can be achieved comparable to that of normal weight concrete.

\subsection{Load Deflection and Cracking Behaviour of Reinforced Baked Clay Beams Subjected to Impact Loading}

Three beams from each group were tested. The beams of each group showed similar

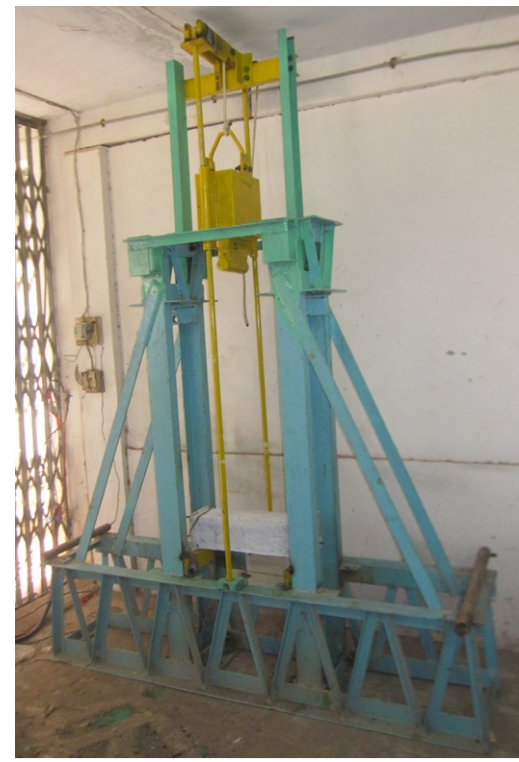

Figure 4. A reinforced baked clay beam of dimensions $150 \mathrm{~mm} \times 150 \mathrm{~mm} \times 500 \mathrm{~mm}$ is being tested for drop weight impact loading. 


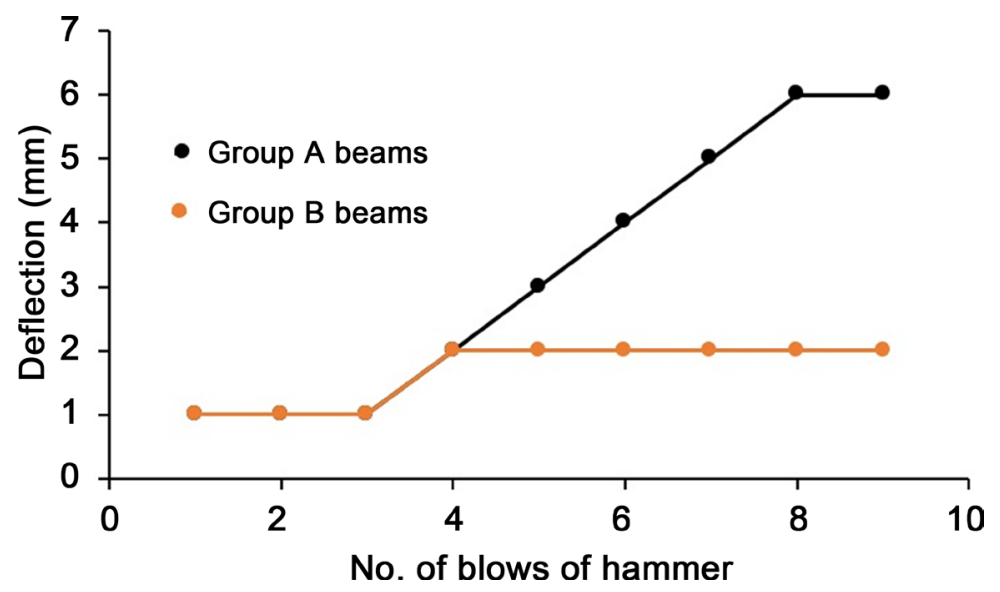

Figure 5. Impact load versus deflection response of RBC beams of group A (with two $12.7 \mathrm{~mm}$ diameter steel bars) and group B (with two $15.8 \mathrm{~mm}$ diameter steel bars).

load deflection behaviour. For convenience of presentation, the results of a representative beam from each group are described. Figure 5 shows load deflection behaviour of $\mathrm{RBC}$ beams of group A and B. It can be observed that the deflection was reduced to three times by increasing the area of steel by $50 \%$. It was also observed that the crack width of beams was decreased to 2.5 times by increasing the area of steel by $50 \%$. All reinforced baked clay beams failed completely within nine blows of drop weight hammer, irrespective of area of reinforcement.

Figure 5 shows that during initial part of impact loading of RBC beams of group A and $B$, the values of deflection are same irrespective of ratio of reinforcement. This is due to same magnitude of compressive strength of both of these groups of beams. The effect of further impact loading was then transferred to reinforcement. This implies that more the area of reinforcement, less the deflection caused by impact loading.

\section{Conclusions}

In this paper, effect of reinforcement on deflection and cracking behaviour of reinforced baked clay beams, subjected to drop weight impact load, was investigated. Following conclusions were drawn:

1) Deflection was decreased to three times when the area of steel was increased to $50 \%$ in RBC beams.

2) Crack width of the RBC beams was decreased to about 2.5 times by increasing $50 \%$ of area of reinforcement.

3) Irrespective of area of steel, failure of all the RBC beams occurred within nine blows of hammer.

\section{Acknowledgements}

The authors would like to thank Quaid-e-Awam University of Engineering, Science and Technology Nawabshah, for providing access to the Structural Engineering Laboratory to conduct the tests mentioned in this study. 


\section{References}

[1] Ansari, A.A., Bhatti, N.K. and Bhutto, A. (2013) Suitability of Pre-Perforated Post-Reinforced Baked Clay Beam Panels for Low Cost Housing. American Journal of Civil Engineering, 1, 6-15. http://dx.doi.org/10.11648/j.ajce.20130101.12

[2] Ansari, A.A. and Lakho, N.A. (2013) Determination of Structural Properties of Baked Clay as Replacement of RCC. International Journal of Emerging Technology and Advanced Engineering, 3, 17-25.

[3] Ansari, A.A. (2008) Experimental Study of the Behaviour of Pre-Perforated Post-Reinforced Baked Clay Panels of Beams. Ph.D. Thesis, Quaid-e-Awam University of Engineering Science and Technology, Nawabshah.

[4] Lakho, N.A. and Zardari, M.A. (2016) Comparison of Compressive and Tensile Strength of Baked Clay with Those of Normal Concrete. Engineering, 8, 301-307. http://dx.doi.org/10.4236/eng.2016.86027

[5] Lakho, N.A. and Zardari, M.A. (2016) Relation between Compressive Strength of Baked Clay Cubes and Cylinders. Engineering, 8, 509-514. http://dx.doi.org/10.4236/eng.2016.88047

[6] Lakho, N.A., Zardari, M.A. and Memon, F.A. (2016) Effect of Intensity of Compaction on Crushing Strength of Indigenous Baked Clay. Journal of Engineering Research, 4, 17-28. http://dx.doi.org/10.7603/s40632-016-0011-5

[7] Lakho, N.A. and Zardari, M.A. (2016) Experimental Study of Flexural Behaviour of Reinforced Baked Clay Beams under Impact Loading. Engineering, 8, 347-352. http://dx.doi.org/10.4236/eng.2016.86032

[8] Lakho, N.A. and Zardari, M.A. (2016) Flexural Behaviour of Reinforced Baked Clay Beams. Engineering, 8, 403-409. http://dx.doi.org/10.4236/eng.2016.86032

[9] Ruiz, G., Pandolfi, A. and Ortiz, M. (2001) Three-Dimensional Cohesive Modeling of Dynamic Mixed-Mode Fracture. International Journal for Numerical Methods in Engineering, 52, 97-120. http://dx.doi.org/10.1002/nme.273

[10] Pandey, A.K., Kumar, R., Paul, D.K. and Trikha, D.N. (2006) Strain Rate Model for Dynamic Analysis of Reinforced Concrete Structures. Journal of Structural Engineering, 132, 1393-1401. http://dx.doi.org/10.1061/(ASCE)0733-9445(2006)132:9(1393)

[11] Vidal, T., Castel, A. and François, R. (2007) Corrosion Process and Structural Performance of a 17-Year-Old Reinforced Concrete Beam Stored in Chloride Environment. Cement and Concrete Research, 37, 1551-1561. http://dx.doi.org/10.1016/j.cemconres.2007.08.004

[12] Wight, J.K. and MacGregor, J.G. (2012) Reinforced Concrete: Mechanics and Design. Pearson Education, Inc., Upper Saddle River, New Jersey.

[13] Lakho, N.A, Zardari, M.A., Memon, M. and Saand, A. (2015) Design and Fabrication of Mechanized System for Casting and Compacting Laboratory Size Clay Beams. Scientia Iranica, 22, 2046-2051.

[14] BS EN 12390-3 (2009) Testing Hardened Concrete-Part 3: Compressive Strength of Test Specimens. Management Centre, Brussels. 
Submit or recommend next manuscript to SCIRP and we will provide best service for you:

Accepting pre-submission inquiries through Email, Facebook, LinkedIn, Twitter, etc.

A wide selection of journals (inclusive of 9 subjects, more than 200 journals)

Providing 24-hour high-quality service

User-friendly online submission system

Fair and swift peer-review system

Efficient typesetting and proofreading procedure

Display of the result of downloads and visits, as well as the number of cited articles

Maximum dissemination of your research work

Submit your manuscript at: http://papersubmission.scirp.org/

Or contact eng@scirp.org 